\title{
Energy efficiency in heritage friendly buildings: a case study in the New Forest (UK)
}

\author{
A. Villacampa \& C. A. Brebbia \\ Wessex Institute of Technology, UK
}

\begin{abstract}
Technical achievements and society's concerns are increasingly demanding energy efficient buildings at different levels. Furthermore, sustainability and conservation of heritage buildings have to be considered by all the actors involved in their life cycle. Owners, users, architects, engineers and landscape planners have to be aware of the importance of renewable resources and the respect for the environment. This is the case of Wessex Institute of Technology and its aim is to apply environmental policies to the conservation of its architecture. The fact that the institution is located in the heart of the New Forest National Park in Southern England implies strong commitments in the refurbishment, re-use and conservation of the buildings related to their location. This process requires respect for the existing architecture with strong historical reminiscences and new heritage friendly buildings. The improvement of the campus through renovation projects aims to the generation of a sustainable group of buildings focusing on energy consumption management. Thanks to this strategy, the design of these improvements takes into consideration the conservation of the architecture, the landscape, waste management policies and the control of energy consumptions. The new and existing buildings energy performances have been tested trough the Simplified Building Energy Method (SBEM) assessment methodology. This evaluation aims to estimate how WIT's architecture can achieve good energy performances on its new and its heritageexisting buildings and form the basis for developing an energy resources strategy.
\end{abstract}

Keywords: heritage buildings, energy assessment, energy efficiency, SBEM. 


\section{The importance of evaluation of energy consumptions in existing and new buildings}

There exist many international organizations nowadays that promote the adoption of policies, methods and tools to achieve a global sustainable built environment. Many different assessment methods have been developed for a better understanding of energy performance and management of buildings. Those methods are becoming tools for architects, engineers, designers and users to understand how to achieve efficiency. These methodologies can be applied to new and existing buildings and vary from one country to the other. In a global scale it is worth to mention some of them like the SB tool (Sustainable Building tool), formerly known as GB tool (Green Building tool), a free tool designed and coordinated by the iiSBE organization in Canada; the USA developed method Leadership in Energy and Environmental Design (LEED); the CASBEE method (Comprehensive Assessment System for Building Environmental Efficiency) developed in Japan; the Building Research Establishment Environmental Assessment Method (BREEAM) widely applied and developed in the UK together with the SBEM (Simplified Building Energy Model); the French system HQE (Haute Qualité Environnementale), the German green building rating system DGNB and the VERDE method developed in Spain. All these computer software systems provide an analysis of the energy consumption of a building following different methodologies and considering diverse aspects that can vary from the design and construction process to the evaluation of existing buildings and post-construction performance assessment. The common background to all these methods is the calculation of energy consumptions of buildings to improve their performance and how to apply proper construction techniques. As the context changes, the buildings will have to be adapted to the environment so the use of natural resources and materials will be the most efficient one for each case. The use of the building will condition all these aspects. Thanks to evaluation methods, it is possible to make an assessment of the buildings at every stage of the project to be compared with its actual performance and determine how to improve it. In this way, the rating of a building will vary according to its efficiency capability. Environmental policies encourage sustainability in architecture as of value for the user and for society.

UK's National Calculation Method (NCM) for the Energy Performance of Buildings Directive (EPBD) is defined by the Department for Communities and Local Government (DCLG) as the procedure for demonstrating compliance with the Building Regulations for constructions other than dwellings in order to calculate their annual energy consumptions and to compare them with the energy performance of analogous "notional" buildings. Both calculations make use of standard sets of data for each activity area and use common databases of construction and service components [1]. A similar process is used to define an "asset rating" according to the EPDB. The NCM allows calculations to be done by a simplified tool based on a set of standards. This software tool developed for DCLG by BRE provides an analysis of a building's energy consumption. SBEM calculates monthly energy consumption and carbon dioxide emissions of a non- 
residential building given a description of the geometry, construction, use, HVAC (Heating Ventilation and Air Conditioning) and lighting equipment. The purpose of SBEM is to produce consistent and reliable assessments of energy use for Building Regulations Compliance and for Building Energy Performance Certification purposes [1].

According to the UK Green Building Council [2], the country is committed to reducing $\mathrm{CO} 2$ emissions by $80 \%$ by 2050 . Moreover, " $40 \%$ of the UK's energy consumption and carbon emissions come from the way buildings are lit, heated and used" [3]. Communities and local government have introduced measures to improve the energy efficiency of buildings including the energy performance certificates (EPCs) for properties providing $A$ to $G$ efficiency ratings and recommendations for improvements; the requirement for public buildings to display energy certificates (DECs); requiring inspections for air conditioning systems and giving guidance and advice for the use of boilers. Since October 2008 all properties -including homes, commercial and public buildings- when bought, sold, rented or built, need an EPC while larger public buildings also have to display an energy certificate. These policies are part of the EU's Energy Performance of Buildings Directive and must be adopted by all member states. The directive comprises a common methodology for calculating the integrated energy performance of buildings; minimum standards on the energy performance of existing and refurbished buildings; energy certifications of new and existing buildings requiring prominent display for public ones for a five-year period; and regular inspection of boilers and central air-conditioning systems including an assessment of heating installations where the boilers are more than 15 years old [4].

As stipulated by the EU, the calculation methodology should consider all the aspects that determine energy efficiency and not only the quality of the building's insulation. This integrated approach must take into account heating and cooling installations, lighting, the position and orientation of the building and heat recovery, among others. This concerns the residential and the tertiary sector (offices, public buildings, etc.) with exception of some historic buildings and industrial sites. Each member state is responsible for fixing the minimum standards. Energy consumption for building-related services is approximately one third of the total energy consumption of the EU [5]. The European Commission considers that significant energy savings can be achieved, helping to accomplish objectives on climate change and security of supply.

\section{Assessment methodology}

In the UK context, Energy Performance Certificates (EPC) and Display Energy Certificates (DEC) must be produced using the relevant calculation tool specified in the National Calculation Methodology (NCM). This applies for all energy certificates whether on buildings in construction, sale or rent, or for public display. A number of different methodologies have been developed (or are in the process of being developed) for different types of building and building condition [6]. 
The UK Government has adopted the current version of the Standard Assessment Procedure (SAP) for energy assessments of dwellings as part of England and Wales national methodology for calculation of the energy performance of buildings. It is used to demonstrate compliance for dwellings with Part L of the Building Regulations 2000 in England and Wales [6].

The SBEM or Simplified Building Energy Model is a tool developed by the Building Research Establishment (BRE) to provide an analysis of building's energy consumptions. This assessment method can be applied to non-domestic buildings according to the NCM, the Energy Performance of Buildings Directive (EPBD) and the Green Deal. The tool also determines $\mathrm{CO}_{2}$ emission rates for new buildings in compliance with Part L of the Building Regulations for England and Wales. It can also be used to generate Energy Performance Certificates for non-domestic buildings on construction, sale or rent. SBEM was developed by BRE for the Department for Communities and Local Government. A variant of SBEM can be used to assess non-domestic buildings for the newly announced UK Green Deal taking account actual metered energy consumption and estimating the savings that can be made by improvement measures [7].

\section{Heritage-friendly architecture in the new forest}

The territorial development of the New Forest National Park in the South of England includes many activities and services that are part of a cultural district development network. Some of these activities are located in Ashurst Lodge, where a group of heritage buildings have been adapted to host different scientific, research, social and environmental activities respecting the traditional style of the buildings that have been transformed into the headquarters of the Wessex Institute of Technology (WIT) among others.

Ashurst Lodge can be easily reached from an important road connecting Lymington to Southampton. It is reasonable to assume that some early habitation may have existed there since some remains of Roman pottery have been found nearby. The site is associated with the origins of the Lodge -its foundations are still visible- where an entrepreneur settled in the New Forest encouraged by Elisabeth I to manufacture saltpetre, material of strategic importance as one of the ingredients of gunpowder. After the middle of 1584 the land returned to the crown and from then on, a series of Forest Keepers took up residence there. In 1708 Ashurst Lodge was burnt to the ground requiring to be completely rebuilt in brick, the trend after the Great Fire of London in 1667. The earliest surviving plans, dated in 1784, show it as a rectangular building of approximately $26 \mathrm{ft}$ by $43 \mathrm{ft}$ in plan $(8 \mathrm{~m}$ by $13 \mathrm{~m}$ ) with a small porch and an attached wash house. Substantial changes were made to the building until the $20^{\text {th }}$ Century. From the beginning of 1921, Ashurst Lodge became a private residence and two new wings were added. The Lodge also played an important role in the planning of the Normandy invasion when it became the headquarters of the Mulberry Harbour units' officers, a team of surveyors and their support staff.

Wessex Institute of Technology (WIT) moved to Ashurst Lodge in 1986. The institution is conceived as a link between academia and industry; advanced 
technology and scientific knowledge transfer. WIT has successfully introduced high quality research activities in the natural environment of the Forest. Every year scientists, researchers and delegates from all over the world join the permanent staff of the institution sharing their perception of the environment and the importance of the heritage of the National Park [8].

\section{Comparative energy assessment of two representative buildings of the Wessex institute of technology}

As a realistic approach to the energy performance assessment and management of the buildings of Ashurst Lodge, there have been selected two representative buildings with different characteristics for their assessment. Because of the variety of typologies and uses of the complex where Wessex Institute of Technology is located, it has been possible to evaluate the energy performance of two substantially different case studies for their comparative assessment.

The first building that has been evaluated was WIT's main building, called the Lodge: the eldest building of the complex. The calculation of its energy efficiency through the SBEM as built helped us to understand its primary resources and current performance. In this particular case, the mixed use of space (offices, meeting rooms, accommodation, kitchen, etc.) gives a specific identity to the building. The evaluation of the preserved heating system, the electricity requirements for the work spaces, the traditional construction materials, the use of new technologies and the state of conservation and maintenance of this former manor house can condition the re-use of the space itself. In this particular case, the study of the old building is to evaluate if the use of traditional resources is appropriate to its present use and, in particular, how the elder boiler performs according to the new energy standards.

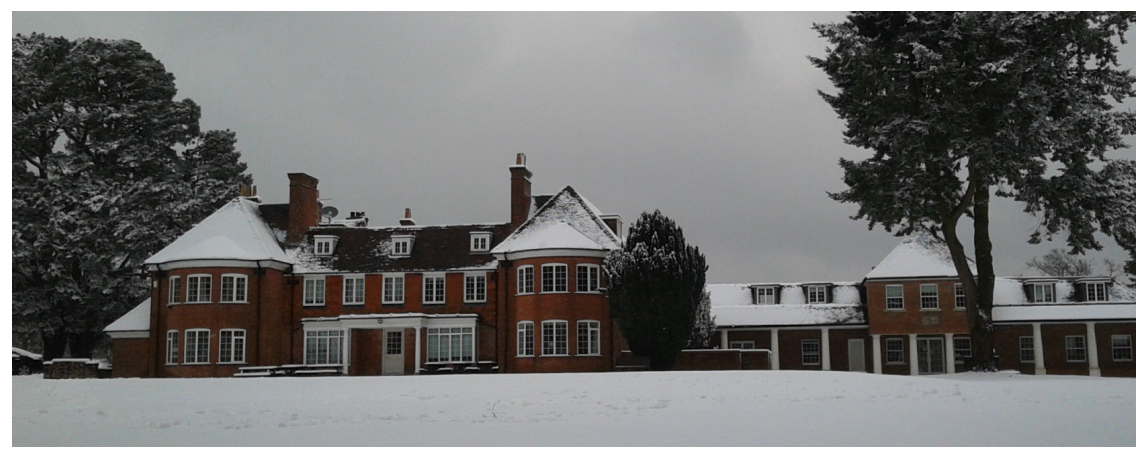

Figure 1: Wessex Institute of Technology; Ashurst Lodge.

The second comparative case study was the new sports building containing the swimming pool, a heritage-friendly design integrated with the existing architecture and within its surroundings. In this case, the use of the SBEM applied as designed helped to evaluate the performance of the building and 
compare the calculated values with the current energy demands. This particular case -an indoor swimming pool- requires a considerable amount of energy to heat up the water and to keep a constant comfort temperature, especially during the winter months. Good isolation and efficient machinery are crucial in this kind of building to optimize energy consumption. Solar panels have been installed as part of the green energy policy of the Institute.

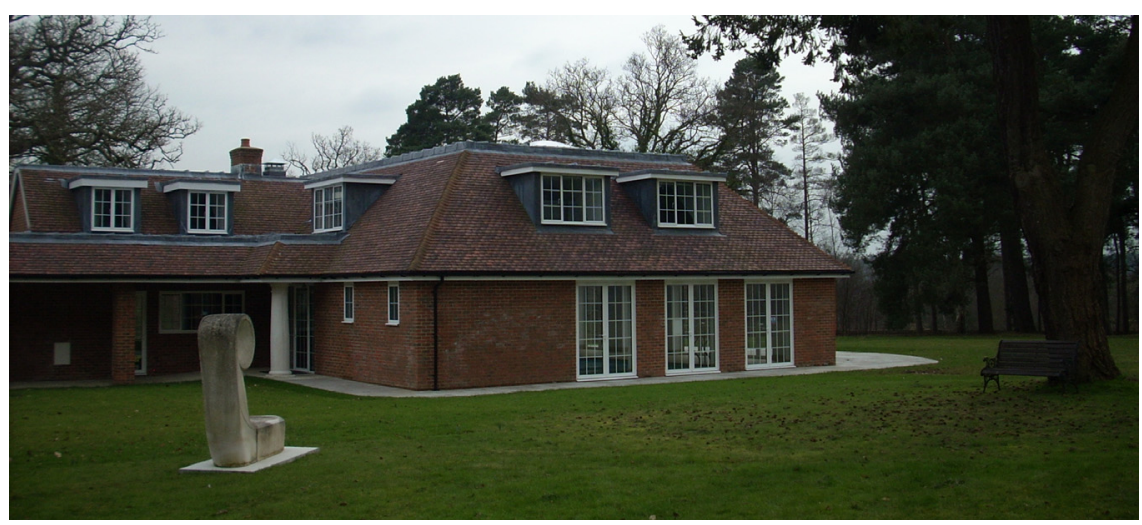

Figure 2: Wessex Institute of Technology; Swimming pool building.

While evaluating the energy performance of a building, local weather conditions have to be considered. For the computer-based calculations, the SBEM applies a pre-set list of parameters for each location that are based on the averages given by the UK's National Weather Service -Met Office. According to their figures, during the months of January and February 2013, the max. average temperature was $-1.5^{\circ} \mathrm{C}$ lower than the average for the period $1981-2010$; and the min. average temperature was $-0.6^{\circ} \mathrm{C}$ lower than the average for the same period. This fact will increase the energy demand for the HVAC in comparison with the results given by the SBEM tool as shown in the calculations. For the period 1981-2010, the coldest months on the location have been January and February, with an average maximum temperature of $8.4^{\circ} \mathrm{C}$ and an average minimum temperature of $1.5^{\circ} \mathrm{C}$; there were 11.6 days of air frost and 66.5 sunshine hours per month [9].

\subsection{The Lodge}

The main building in Ashurst Lodge has been divided in three zones each one heated by one of the three existing boilers. Each zone corresponds to a different construction phase of the building. The aim of this study is to identify the energy efficiency of the older part of the building in terms of electricity and fuel consumption. The SBEM has been applied to assess this part of the building so that its results can be compared with the actual performance.

The area that has been analysed has $450 \mathrm{~m}^{2}$, comprises zones with HVAC systems, has natural ventilation and a HWS (Hot Water System). The fuel used 
for the HVAC and HWS is gas oil (red diesel). The exterior envelope is a pre1990's cavity wall system and after a relatively recent refurbishment of the building, foam insulation has been sprayed inside the cavity and all windows are double-glazing aluminium.

Focusing again on the two coldest months of the year, it can be seen that, according to the SBEM, the heating and HWS demand for January 2013 was $42.27 \mathrm{kWh} / \mathrm{m}^{2}$ and for February 2013 it was $29.54 \mathrm{kWh} / \mathrm{m}^{2}$, emitting a total of $7760.65 \mathrm{Kg}$ of $\mathrm{CO}_{2}$ for the two-month period.

The SBEM analysis of the electricity demand for the two winter months (January \& February) suggests the Lodge will need $5.87 \mathrm{kWh} / \mathrm{m}^{2}(2641.5 \mathrm{kWh})$ over each month, with a total of $1268.8 \mathrm{Kg}$ of GHG (Green House Gas) emissions.

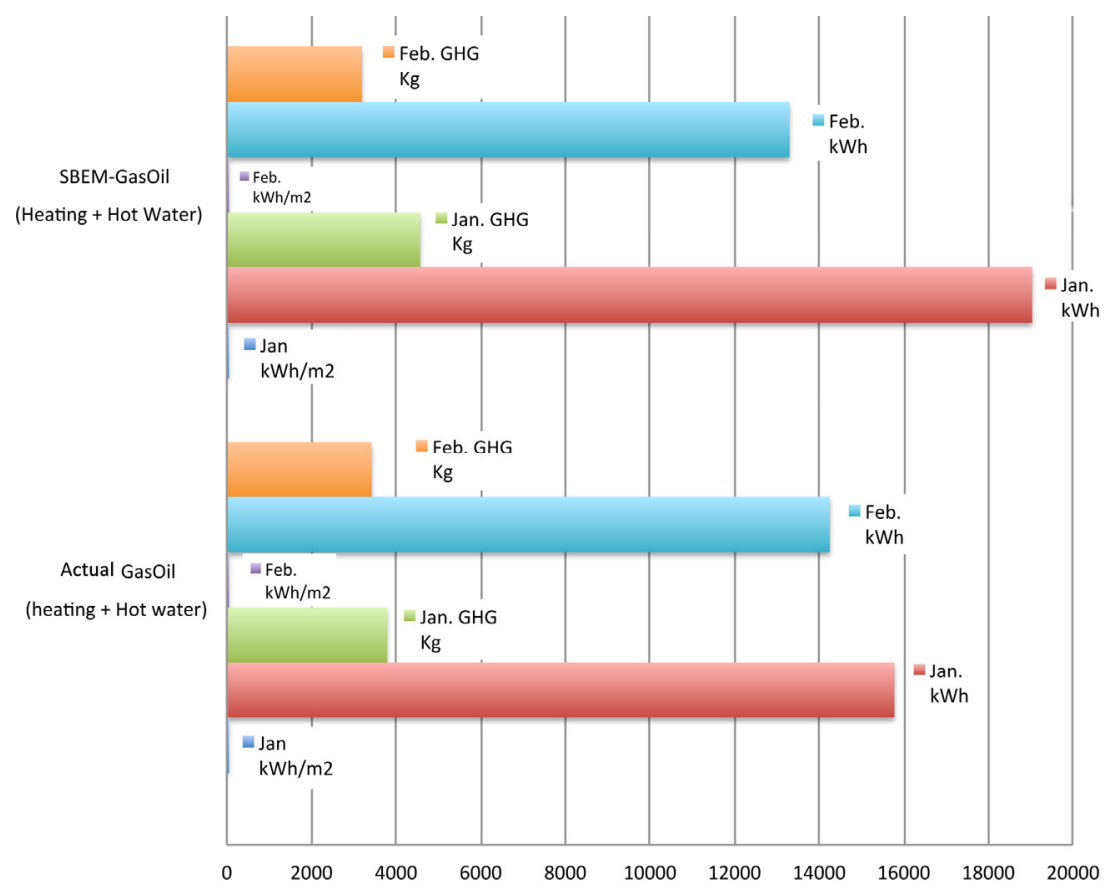

Figure 3: Old part of the Lodge's winter energy demand according to SBEM and its actual use.

Following the parameters given by the SBEM report, the Lodge, as built, should have consumed 3047.22 litres of red diesel during the months of January and February, which results in $32314.09 \mathrm{kWh}$ for that period $\left(71.81 \mathrm{kWh} / \mathrm{m}^{2}\right)$. These figures can be compared with the actual red diesel consumption for January and February (figure 3), when the Lodge used 2832 litres of oil, which means $30032 \mathrm{kWh}\left(67 \mathrm{kWh} / \mathrm{m}^{2}\right)$. According to the SBEM (figure 4), the old part of the lodge is estimated to emit, during January and February, a total of $7738.4 \mathrm{Kg}$ of $\mathrm{CO}_{2}$ instead of the $7207.67 \mathrm{Kg}$ of $\mathrm{GHG}$ that have been generated. 
According to the SBEM calculated annual heating consumption, the oil use of the Lodge for January and February is $30 \%$ of the total, an estimate that will be used when calculating the actual annual energy consumption.

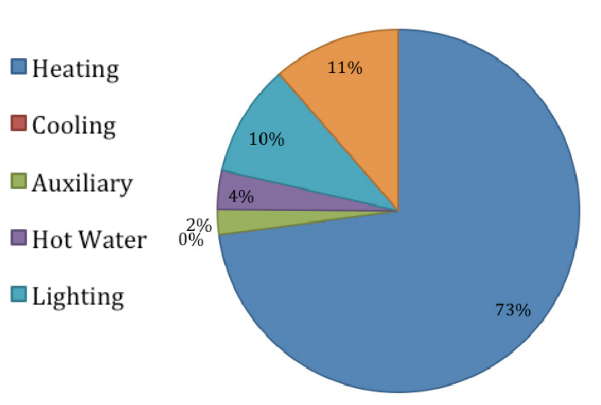

\begin{tabular}{|l|r|r|}
\hline & $\mathbf{k W h} / \mathbf{m}^{\mathbf{2}}$ & \multicolumn{1}{c|}{$\begin{array}{c}\text { GHG } \\
\mathbf{K g}\end{array}$} \\
\hline Heating & 201.76 & 23460.8 \\
\hline Cooling & 0 & 0 \\
\hline Auxiliary & 6.27 & 729.1 \\
\hline Hot Water & 9.53 & 1108.2 \\
\hline Lighting & 27.71 & 3222.1 \\
\hline Equipment & 31.58 & 3672.1 \\
\hline TOTAL & 219.59 & 25534.1 \\
\hline
\end{tabular}

Figure 4: $\quad$ The Lodge's annual energy consumption according to SBEM [7].

\subsection{The swimming pool}

The swimming pool building is the newest of the complex, dedicated to indoor sports, and with an area of $270.42 \mathrm{~m}^{2}$ divided in two levels. The building has two HVAC systems; the fuel in use is kerosene and the HWS has a central heating boiler with 300 litres storage and a thermosiphon circulation system. Its $16 \mathrm{~m}^{2}$ of solar panels are oriented to South and used for the HWS.

Since the annual heating demand varies during the year, the calculations taken as a reference were the ones for January and February when the energy consumption is larger. Indeed, the SBEM curve for the monthly calculations show that the heating use of the swimming pool building during January and February represent $25 \%$ of the heating demand of the whole year. According to the SBEM calculations, for the month of January the swimming pool building, as designed, will demand $27.37 \mathrm{kWh} / \mathrm{m}^{2}$ generating a monthly $\mathrm{CO}_{2}$ emission of

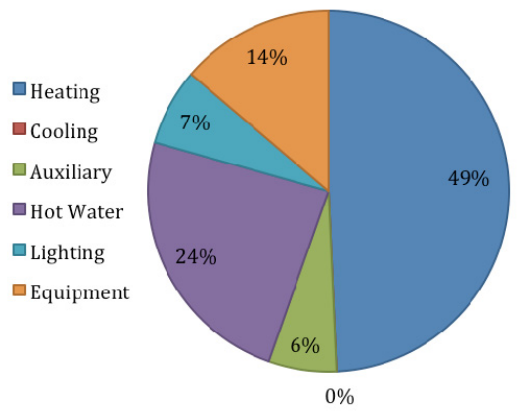

\begin{tabular}{|l|r|r|}
\hline & $\mathbf{k W h} / \mathbf{m}^{2}$ & $\begin{array}{c}\text { GHG } \\
\mathbf{( K g )}\end{array}$ \\
\hline Heating & 125.5 & 14596.7 \\
\hline Cooling & 0 & 0 \\
\hline Auxiliary & 15.5 & 1796.5 \\
\hline Hot Water & 61.1 & 7103.9 \\
\hline Lighting & 17.5 & 2037.2 \\
\hline Equipment & 35 & 4074.5 \\
\hline TOTAL & 219.6 & 25534.1 \\
\hline
\end{tabular}

Figure 5: Swimming Pool's annual energy consumption according to SBEM [7]. 
$3181.44 \mathrm{Kg}$. For the month of February, the energy demand is assumed to be about $20.99 \mathrm{kWh} / \mathrm{m}^{2}$ emitting $2440.73 \mathrm{Kg}$ of GHG. These figures can be compared with the annual demand of the building shown on figure 5 .

This means that for those two winter months, the swimming pool building is expected to demand 1275.24 litres of kerosene for the HVAC and HWS and to consume about $11.45 \mathrm{kWh} / \mathrm{m}^{2}(3091.5 \mathrm{kWh})$ of electricity (figure 6); this will generate $1332 \mathrm{Kg}$ of GHG for that period.

These figures can be compared with the actual fuel consumption for January and February 2013 of 2492.75 litres of kerosene (42.25 1/day) to heat the air temperature and the water. According to the electricity metered during that period, the pool building required in January $1522 \mathrm{kWh}$ and in February 1859 $\mathrm{kWh}$ of electricity, emitting during those two months a total of $1454 \mathrm{Kg}$ of $\mathrm{CO}_{2}$. Comparing the $\mathrm{CO}_{2}$ emissions calculated by the SBEM as designed $(1331.4 \mathrm{Kg}$ ) and the actual one, the actual Building Emission Rate (BER) is higher than the Target Emission Rate (TER) with a value of 83.65 whereas the SBEM predicted a $\mathrm{BER}=76.2$ which is almost the same as the target rate.

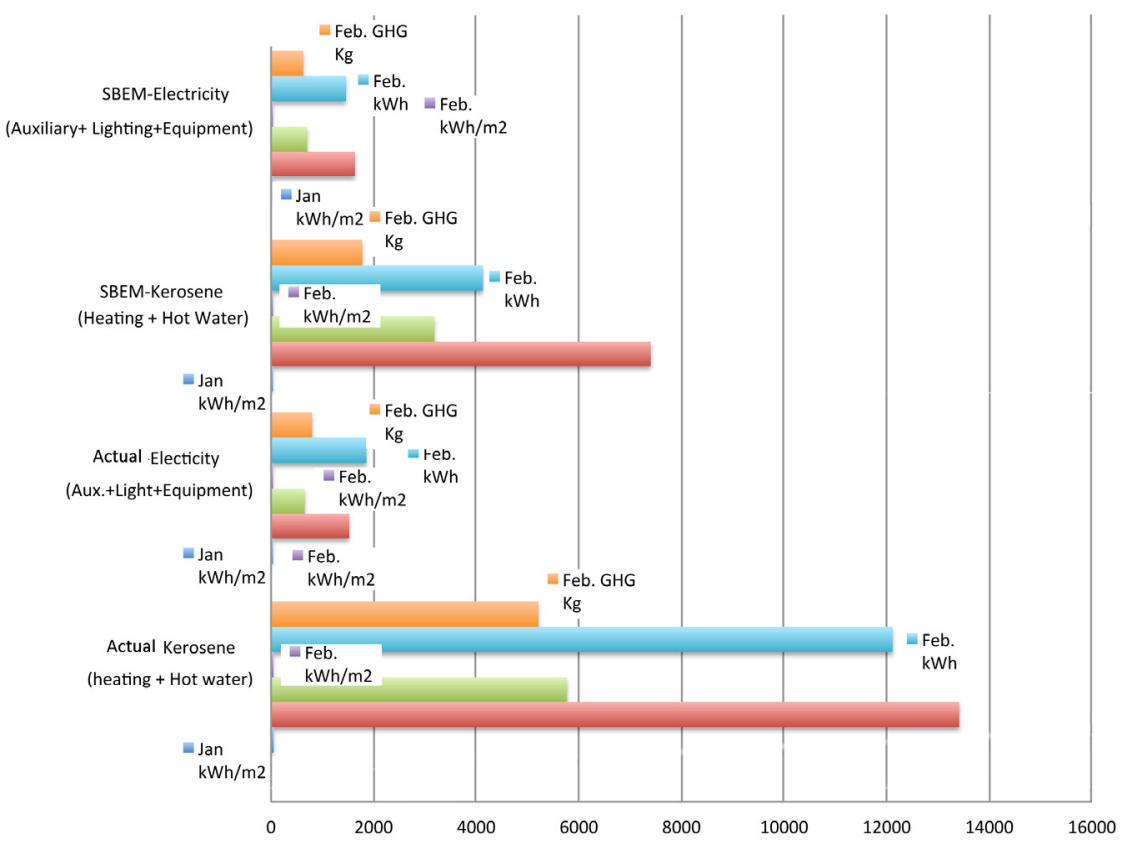

Figure 6: Swimming Pool's winter energy demand according to SBEM compared with the actual use.

As it has been previously mentioned, the building consists of an indoor swimming pool with additional heat losses due to the water evaporation and the heat transfer of the walls of the pool itself that was not taken into account in the previous calculations. As a consequence, the energy demand generated by these 
heat losses needs to be estimated. It has been observed that the SBEM does not have a specific category for this kind of case study. Because of this, the energy demand according to the SBEM was lower than the actual one. In addition, as the winter months that have been monitored (January \& February 2013) have been colder than average, an increase of the use of fuel could be expected. For this study, it has been estimated that the pool has an annual evaporation loss of $2724 \mathrm{~W}$ and a heat loss through the walls of the pool of $480 \mathrm{~W}$. Based on this, the total energy losses for the pool itself are $28067 \mathrm{kWh} /$ year or approximately $30000 \mathrm{kWh} /$ year. For the coldest winter months, January and February, the evaporation and transmittance losses are $7014 \mathrm{kWh}$ that have to be added to the energy demand of the whole building in order to achieve the total consumption levels.

\section{Conclusion}

There exist several energy performance assessment methods to calculate the energy demand of a building. For the analysis of two buildings located at the Wessex Institute of Technology headquarters in the South of England, the SBEM method has been applied. The results of the assessments have been subsequently compared with the actual consumption of the buildings (table 1). Both constructions have a different use and size and they have been built in different periods with diverse construction techniques. Due to the context where the buildings are located, the New Forest National Park, the heritage-friendly factor has been crucial for the design of both buildings. Nevertheless, sustainability and low carbon emission rates are nowadays strongly encouraged by the forest authorities. The aim of this study was not only to compare the energy efficiency of new heritage-friendly buildings with the existing ones but also to find out how close to the actual demand were the assessments generated by the SBEM. The conclusions are to be taken into consideration for further improvements of the buildings and development of an energy strategy for the WIT campus as a whole.

It has been reported that the accuracy of the SBEM method is more precise when applied to new buildings than when applied to old buildings. Moreover, the SBEM evaluation of the new building was done at the design phase whereas the one for the existing edifice was carried out after built. In the case of the swimming pool (a new heritage-friendly building), the energy performance rating according to the SBEM is satisfactory if compared to the benchmark for newly built similar buildings. Nevertheless, the energy losses of the pool were not reflected in the original assessment. In the case of the old part of the Lodge, the energy performance rating is below the benchmark for newly built similar buildings but it is in the same range as the typical existing stock.

An important aspect of the feedback given after the SBEM assessment is how to reduce the green house gas emissions by technical improvements. When the evaluation is done during the design process the SBEM is a reliable tool to reduce the low carbon emissions but, when the assessment is for an old building with a different use than originally, the improvements have to take into account other factors like the age of the building, the area restrictions, the state of the 
Table 1: Comparison of both buildings during two winter months (Jan. and Feb.) and the whole year.

\begin{tabular}{|c|c|c|c|}
\hline \multirow{2}{*}{$\begin{array}{l}\text { SBEM-Swimming Pool } \\
\quad(\text { Jan+Feb 2013) }\end{array}$} & \multirow{2}{*}{23000} & $\begin{array}{c}63 \% \\
\text { Kerosene } \\
\end{array}$ & $14500 \mathrm{kWh}$ \\
\hline & & $\begin{array}{c}37 \% \\
\text { electricity }\end{array}$ & $8500 \mathrm{kWh}$ \\
\hline \multirow{2}{*}{$\begin{array}{l}\text { Actual use-Swimming Pool } \\
\quad(\text { Jan+Feb 2013) }\end{array}$} & \multirow[b]{2}{*}{$29000 \mathrm{kWh}$} & $\begin{array}{c}86 \% \\
\text { Kerosene }\end{array}$ & $25000 \mathrm{kWh}$ \\
\hline & & $\begin{array}{c}14 \% \\
\text { electricity }\end{array}$ & $4000 \mathrm{kWh}$ \\
\hline \multirow{2}{*}{$\begin{array}{c}\text { SBEM-Lodge } \\
\text { (Jan+Feb-average) }\end{array}$} & \multirow{2}{*}{$37000 \mathrm{kWh}$} & $\begin{array}{c}84 \% \\
\text { Red Oil }\end{array}$ & $31000 \mathrm{kWh}$ \\
\hline & & $\begin{array}{c}16 \% \\
\text { electricity }\end{array}$ & $6000 \mathrm{kWh}$ \\
\hline \multirow{2}{*}{$\begin{array}{l}\text { Actual use-Lodge } \\
(\text { Jan.+Feb-2013) }\end{array}$} & \multirow[t]{2}{*}{$33400 \mathrm{kWh}$} & $\begin{array}{c}90 \% \\
\text { Red Oil }\end{array}$ & $30000 \mathrm{kWh}$ \\
\hline & & $10 \%$ elect. & $3400 \mathrm{kWh}$ \\
\hline \multirow{2}{*}{$\begin{array}{l}\text { SBEM-Swimming Pool } \\
\text { (year-average) }\end{array}$} & \multirow[b]{2}{*}{$92000 \mathrm{kWh}$} & $\begin{array}{c}85 \% \\
\text { Kerosene }\end{array}$ & $78000 \mathrm{kWh}$ \\
\hline & & $\begin{array}{c}15 \% \\
\text { electricity }\end{array}$ & $14000 \mathrm{kWh}$ \\
\hline \multirow{2}{*}{$\begin{array}{l}\text { Actual use-Swimming Pool } \\
\text { (estimated for year 2013) }\end{array}$} & \multirow[b]{2}{*}{$116000 \mathrm{kWh}$} & $\begin{array}{c}88 \% \\
\text { Kerosene }\end{array}$ & $100000 \mathrm{kWh}$ \\
\hline & & $\begin{array}{c}12 \% \\
\text { electricity }\end{array}$ & $13200 \mathrm{kWh}$ \\
\hline \multirow{2}{*}{$\begin{array}{l}\text { SBEM-Lodge } \\
\text { (year-average) }\end{array}$} & \multirow{2}{*}{$148000 \mathrm{Kwh}$} & $\begin{array}{c}77 \% \\
\text { Red Oil }\end{array}$ & $100000 \mathrm{kWh}$ \\
\hline & & $\begin{array}{c}23 \% \\
\text { electricity }\end{array}$ & $30000 \mathrm{kWh}$ \\
\hline \multirow{2}{*}{$\begin{array}{l}\text { Actual use-Lodge } \\
\quad \text { (year 2013) }\end{array}$} & \multirow[t]{2}{*}{$135000 \mathrm{Kwh}$} & $\begin{array}{c}85 \% \\
\text { Red Oil }\end{array}$ & $115000 \mathrm{kWh}$ \\
\hline & & $\begin{array}{c}15 \% \\
\text { electricity }\end{array}$ & $20000 \mathrm{kWh}$ \\
\hline
\end{tabular}

boilers and heating system (for some specific cases, the original design of the building can include traditional heating systems that are as efficient as contemporary ones). The costs for the improvement of an old building are not only based on financial conditions but also arise from aesthetics criteria. Introducing, for instance, solar panels on a heritage-friendly context depends not only on the location and the orientation of the building itself but also on how it can affect the architecture. In addition, for some specific cases, the engineering services of an old building can be considered as heritage items themselves according to the UK planning regulations. In these cases, the desirable energy performance levels may not be reached due to conservation requirements. In our case studies, the performance of both buildings has been monitored during a particularly cold winter and compared with the SBEM assessment. This fact has generated higher energy consumption in both buildings than expected according to the SBEM. In addition, the SBEM database excluded the pool itself. This has led to remarkable differences in the output SBEM calculations when compared 
to the actual energy consumption of the sports building. It has been estimated that such a difference is due to the exclusion of the water heat losses of the pool (evaporation and wall heat transmission) from the SBEM evaluation. In the case of the Lodge, its change of use and its age does not seem to have created significant differences between the SBEM assessment and the actual performance. Further construction improvements must keep into account these factors. Moreover, the actual electricity and fuel consumption have been monitored for the winter period in order to achieve the comparison shown on table 1 . For these results, the \% of electricity and fuel have been calculated according to the SBEM monthly demand for electricity, heating, hot water and air-conditioning demand and then compared with the monthly estimated $\%$ of actual fuel and electricity used at the lodge and the swimming pool building.

According to the EPDB-NCM [10], the SBEM methodology is not intended to be a design tool and in the cases where the performance of a particular feature is critical to the design, it is recommended to use more accurate modelling tools. In the buildings evaluated here, the actual performance of the swimming pool building had to be studied considering the energy demand of the pool itself as an additional feature to be added to the SBEM calculations in order to reach a satisfactory agreement. Nevertheless, the assessment generated by the SBEM tool for an old building, the Lodge, and its comparison with the actual energy consumption have been in satisfactory agreement. The monitoring of energy use for both buildings will continue in order to provide more data and being able to draw more accurate conclusions.

\section{References}

[1] EPBD-NCM National Calculation Method; Building Research Establishment Ltd. 2009; [on-line] www.ncm.bre.co.uk

[2] Climate change, energy and carbon emissions; UK Green Building Council; Key statistics, 2013 [on-line] http://www.ukgbc.org/content/keystatistics-0

[3] Energy performance of buildings; Department for Communities and Local Government; UK, 2013 [on-line] https://www.gov.uk/government/ policies/improving-the-energy-efficiency-of-buildings-and-using-planningto-protect-the-environment/supporting-pages/energy-performance-ofbuildings

[4] Sustainable constructions of buildings; Sustainability \& BREEAM; BRE Group, 2013 [on-line] http://www.bre.co.uk/page.jsp?id=9

[5] Energy efficiency: energy performance of buildings; Europa. Summaries of EU legislation; 14 February 2007 [on-line] http://europa.eu/legislation summaries/other/127042_en.htm

[6] Assessment methodology and software; Planning, building and the environment. Communities and Local Government; 22 October 2008 [online] http://webarchive.nationalarchives.gov.uk/20120919132719/http:/ www.communities.gov.uk/planningandbuilding/theenvironment/energyperf ormance/energyassessment/methodologysoftware/ 
[7] SBEM Simplified Building Energy Model; BRE Group, 2012 [on-line] http://www.bre.co.uk/page.jsp?id=706

[8] Brebbia, C.A. The New Forest: A personal view. WIT Press, Southampton \& Boston, 2008 ISBN: 978-1-84564-145-0

[9] Met Office; UK weather and climate statistics. Climate averages; 2013 [online] http://www.metoffice.gov.uk/climate/uk/averages/

[10] iSBEM User Guide; EPBD-NCM National Calculation Method; Building Research Establishment Ltd. 2009; [on-line] http://www.ncm.bre. co.uk/download.jsp 